\title{
A Century of Materials Come and Gone
}

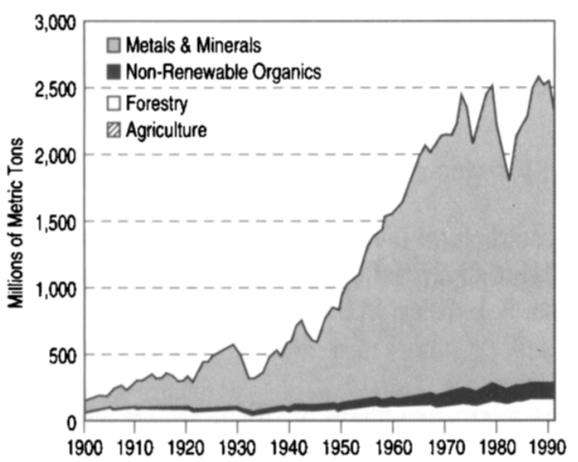

Figure 1. U.S. Consumption of Raw Materials (1900-1991). Source: U.S. Bureau of Mines.
In 1994, during a conference on materials and the environment, Donald G. Rogich, then head of a sleepy and now defunct corner of the U.S. bureaucracythe Division of Mineral Commodities of the Department of Interior's Bureau of Mines (BOM) - presented graphs of materials used since the 1900s. (The BOM closed down in January 1996, but part of the function of the Division of Mineral Commodities continues with a reduced staff in the new Office of Minerals Information in the U.S. Geological Survey.) A summary graph of his presentation entitled "U.S. Consumption of Raw Materials" (see Figure 1) depicted the trends in materials during the twentieth century.

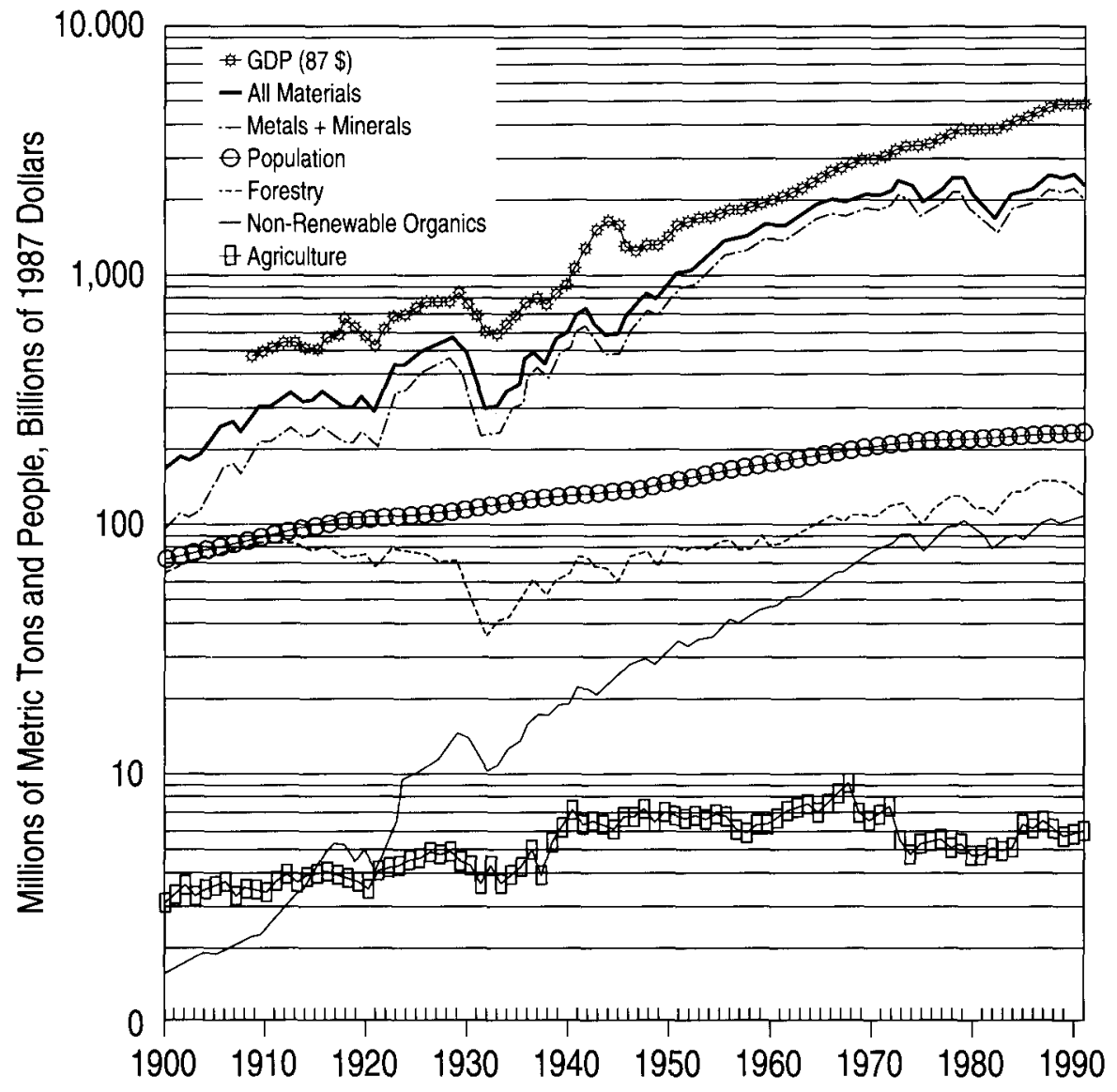

Figure 2. U.S. Consumption of Materials (1900-1991). Source: U.S. Bureau of Mines.
The graph's jagged lines and upward surge depict close to every bit of material out of which something was built, constructed, manufactured, or produced in the United States since 1900. In the 90 years represented, the U.S. population rose from under 80 million to about 250 million. The world of horse-drawn carriages and gas lighting transformed into high-tech modernity. Depicted in this graph are the brick, concrete, asphalt, steel, copper, aluminum, chromium, rubber (natural and synthetic), wood, glass, silk, cotton, paper, lubricants, petrochemicals, plastics, composites, silicon, gold, and other nonfuel, nonfood materials that comprise 90 years worth of economic, military, and industrial activity of the United States.

Referring to Figure 2, in 1900, the nation's 80 million citizens used less than 200 million metric tons of materials, virtually derived from metals, minerals (mostly for construction materials), and wood. In 1900, new kinds of plastics such as the semisynthetic cellulose-based materials were very small players in the materials landscape finding low-volume roles in such items as film, combs, and personal hygiene products.

In 1990, total (nonfood, nonfuel) material consumption was in the 2,500-millionmetric-ton range, or more than 20,000 pounds for each U.S. citizen (BOM estimates put global consumption of all material in 1990 at just under 8,000 million metric tons). In 1990, most U.S. material use by weight still resided in metals, mineral, and wood. In that sense, little has changed. Since the end of the second world war, however, the material landscape has been increasingly filled with synthetic materials based on "non-renewable organics" such as petroleum which today provide the major feedstocks for petrochemicals, plastics, and synthetic fibers.

IVAN AMATO

FOR FURTHER READING: D.G. Rogich et al., "Changing Minerals and Materials Use Patterns," (U.S. Bureau of Mines, 1994) presented at the Annual General Meeting of the Academia Europaea. Figures 1 and 2 reproduced with permission. 